\title{
Water and Wing Give Wonder: Trans-species Cosmopolitanism
}

\author{
Cynthia Willett
}

Of the first philosophers, then, most thought that the principles which were of the nature of matter were the only principles of all things. ... Thales, the founder of this type of philosophy, says the principle is water. (Aristotle 983b5-20)

Is it not possible that these performances are stimulated by feelings akin to wonder and awe? ...What is it, this water? (Goodall 1304, on chimpanzee waterfall dances)

\section{Introduction: Philosophy Begins In Wonder}

Wandering along a stream in Gombe National Park in Tanzania, anthropologist Barbara Smuts was following the usual path to the sleeping trees. Smuts has often made sojourns to study primate social behavior, and she had already documented the social manners encountered among her baboon friends in the African parks. On this particular occasion, however, something strange happened. The wild troop of baboons did not proceed forward at their typical pace but instead paused and sat motionless by the stream's still pools for moments of "silent contemplation" (Smuts 301). Searching for some word to give to the astonishing posture of reverence among the monkeys, Smuts settled on a Buddhist term for a spiritual community: "I was stunned by this mysterious expression of what I have come to think of as baboon sangha" (301). ${ }^{1}$

Any interspecies ethics could do well to flip the claim of human exceptionalism several times on its head. ${ }^{2}$ Before entertaining a claim to re-naturalize human beings (with the risk of a reductive model of biology), the remarkable communicative, cultural, and cognitive skills of 
other creatures deserve more investigation. The usual line-up of metaphysical suspects for shoring up human superiority-impartial reason, moral or spiritual freedom, and selfawareness - have been used to gravely overstate our human capacities while obscuring genuinely mind-bending powers that cross species barriers. If there is a common path for ethical and spiritual enlightenment, ${ }^{3}$ as an alternative to humanism's rational enlightenment, it does not seem to originate in any cross-species capacity for high-level reason but in an affect-laden social intelligence instead.

Humans and other animals have a range of capacities for ordinary ethical engagements with fellow creatures. This engagement occurs typically in everyday interactions not through the conscious application of abstract moral principles but as an ongoing tacit negotiation of the modes of reciprocity and the social norms that are required to maintain groups and communities. Ordinary communication-based ethics does not rely on the normative features (abstract rules) of modern institutions and states as defended in the moral traditions of Kant or J. S. Mill (even if large-scale societies have come to depend in part upon abstract rules (Diamond 49-54)).

While humans are armed with a range of "rational" laws, not just democratic but also fascist or capitalist and neoliberal, it is not clear if these laws have raised us above other social animals with regard to fairness and the treatment of others. Our lauded reason has been viewed as our great hope against evil. However, consider for a moment how this reason is manifested in actual laws or moral judgments, shaped as they are by special interests, perfected in the hands of wealthy elites, and enforced through corporate or state bureaucracies. How would we know whether the very confidence that assures us that our own reasoning rises above these instrumental uses is not in fact, from an outsider perspective, hubris? Or, if our sophisticated cognition functions among the technologies of power that blindly but profitably structure 
domination and exploitation? For thousands of years, one man's reasoning-whether Plato's or Marx's or some other's — strikes his rivals as a ruse of power, and once again reason falls short of bringing any real peace to the world.

Yet, we humans have more than one trick up our ethical sleeve; and, as it turns out, so do other animal species. Social carnivores, corvids, dolphins, elephants, the great apes, and even monkeys display expectations, desires, intentions, and some funny fetishes, that not only sustain the groups that they depend upon to survive but that can generate some surprisingly generous social interactions as well. Consider the sexual politics of bonobos. The bonobo policy of substituting sex for aggression renders them, in Frans de Waal's phrase, "the hippie apes" that "make love, not war" (de Waal). This sexy social policy may not serve as a cosmopolitical formula for trans-species peace, but it does not hurt to wonder what other practices for peacemaking might be cultivated among us and other species. We humans have been quick to point out the cognitive limitations of nonhuman creatures in view of our own big-brain achievements. We have insisted that other animals' cognitive processes lack the advantages of linguistic signs (words and propositions) and are restricted to a loose stream of affect. We forget, however, that as a species we humans at least since the time of Aristophanes' Lysistrata may be lagging somewhat behind on playful peace-making skills, at least by bonobo standards (Dubner).

The peaceful reflections of the baboons at the African stream's still pools offer intriguing hints of what may be a more widely shared experience of enlightened repose. The still waters seem to unlock for these primates a sacred experience of unity with nature not unlike what may be found in the meditative practices of Buddhists and other spiritual communities. Of course, these spiritual experiences are rarely an everyday event for any group of animals, human or not; but they do suggest animal capacities for transposing ordinary life into a dream of cosmic peace. 
Such a dream of peace would be fragile at best, and by ordinary standards would strike anyone as a bit mad, and it should. Animals cannot survive without preying on members of other living species and will resort to murderous territorial rages even against their own kin. But what if such madness (the cosmic dream, not the territorial rages) is a more common experience than one would first think? Of course, it is also true that madness has many manifestations-some admirable in their own way, some more ambiguous. Svante Pääbo, the world-renowned head of the Max Planck Institute for Evolutionary Anthropology, suspects that a certain kind of "madness" is a uniquely human trait that accounts for mind-rending feats of technological and planetary domination. Pääbo has speculated that, some 45,000 years ago, propelled by a "Faustian" madness, modern hominins became the only primates who dared to cross open water (Kolbert). Could the serene reflections by the African water pools open a path for another kind of madness, this time one that is neither uniquely human nor bent on domination? Countering that demonic impulse that may well be caused, as Pääbo hypothesizes, by a Faustian gene, this peace by the water echoes the calm contemplative features of a madness once upon a time called divine.

\section{Divine Madness and the Monkey Narcissus Gene}

Plato's Symposium and Phaedrus are among ancient philosophical dialogues devoted to the role of madness in ethical and spiritual vision. Asking the question "What is love?" (eros), the Symposium offers not final answers but seductive fragments of a myth that Socrates learns from a priestess and mystic named Diotima. In the Phaedrus, Socrates and an interlocutor sit by a stream to ponder the nature of the soul, inspired by their "divine madness." Divine madness is said by Plato to compel the seeker of wisdom to suspend ordinary passions, which are portrayed 
for his students as sexual, erratic and debasing: "the slavish love of isolated cases of youthful or human beauty." In Plato's divine madness the seeker finds instead a spiritualization of erotic passion, a tranquil counterpart to Dionysian frenzy and Buddhist Tantra. This higher love (eros) takes one by surprise as an experience of overpowerment, not through the sexual allure of another body, but through the deep stillness of "the vast sea of beauty...that every other beautiful object somehow partakes of," as the mystic priestess reveals to an unknowing Socrates (Plato 210d-211b).

Philosophical reflection transcending ordinary passions can occur in a restful pose by a stream or a sea, as Plato teaches us, where near magical glimpses into cosmic tranquility are found. Could the pause of the baboons by the running waters of the African stream offer for these primates some similar vision of cosmic peace? And if so, wouldn't this heightened ethical vision be grounded, not in any cognitive or linguistic skill peculiar to the superior primates (a subset of the ones without tails), but on a common plane of an elevated affect-a plane that monkeys and humans might share with a range of other creatures? And what if this spiritualization of affect grows out of - not what Plato, Nietzsche, Freud, and Marcuse supposed to be eros' wild sexual energy—but a sublimated primordial mammalian social eros instead?

Impartial reason is the uniquely human capacity proposed to account for how ethics might be extended beyond friends, kinship groups, and others with whom we share interests and attachments, and embrace through cold moral logic the stranger. Yet, recent science and critical theory cast doubt on any moral capacity for decision-making that is metaphysically free from affects, cultural wisdom, and social beliefs. Critical theory raises suspicion against any claim to an objective moral stance that would be unburdened by the non-rational politics of cultural, racial, historical, or socio-economic (and species) identities. In a similar vein, psychologists have 
established through studies of brain injury that an affectless creature relying on reason alone lacks the capacity to make any decision at all (Damasio). Affects, including those nasty biases borne of in-group/out-group social dynamics, shape decisions, including judgments of the moral worth of others. Warped social fields, for good and for bad, curve the waves of affect upon which our individual selves, with our powers of reason, speech, and imagination, swim. ${ }^{4}$ Even Plato, who may aim to usher in a "logocentric" moral system, can only manage to cast his obscure vision through puzzling fragments of arguments mixed with images, myths, and often even logical fallacies! In fact, a definitive account of reason never appears anywhere in the history of Western philosophy--what reason means remains open to debate, disagreement, and speculation. Rival schools of thought (ranging from dialectical Hegelian or Marxist philosophies to Kantian or utilitarian traditions among others) continue to diverge wildly from one another. In these contexts, reason functions as a tribal marker. Ordinarily, like other social animals, we help our own, harm our enemies, and ignore others.

Still, our common animal status is nothing to be ignored, not if it holds open paths to enlightenment. Barbara Smuts's discovery of sangha among her baboon friends conjures an enchanted world where fellow creatures might cross over species lines to ponder together. Imagine a monkey Narcissus gene countering Pääbo's Faustian one. ${ }^{5}$ Monkey brains might not be capable of grasping an abstract concept of the sacred, let alone of elaborating any philosophical system of moral or theological thought; the capacity for highly abstract and systematic thinking may indeed be unique to modern, technologically-driven humans (de Waal et al 161-181). But a phenomenological approach suggests that the tranquil or ecstatic heights of spiritual states and enlightenment are not experienced as conceptual anyway (Steinbock). In fact, as anyone who has practiced yoga, meditation, or simple prayer knows, too much thinking can 
block the practitioner from the experience of a spiritual core. A sacred place or practice frees the mind of moral judgments, weighty abstractions, and everyday beliefs, opening the psyche to elevated feelings of wonder or awe. The boundless uplift of these feelings may be prompted by witnessing natural wonders in the upward direction, from "the starry sky above," as Kant attests, or, as for Thoreau, from the uncertain depths of Walden Pond.

"People often refer to viewing great art, hearing a symphony, or listening to an inspiring speaker as (crypto) religious experiences," Jonathan Haidt observes. He distinguishes these spiritual experiences from symptoms associated with mental disorders:

When the hallucinogenic drugs LSD and psilocybin became widely known in the West, medical researchers called these drugs 'psychoto-mimetic' because they mimicked some of the symptoms of psychotic disorders such as schizophrenia. But those who tried the drugs generally rejected that label and made up terms such as 'psychedelic' (manifesting the mind) and 'entheogen' (generating God from within). (Haidt 201)

The use of animal tropes as abject figures of wild savagery and exotic limit experiences is sheer projection. No doubt these images are fostered in part by a misunderstanding of the traumatized animals in the psych wards that we call factory farms, research labs, circuses, and some zoos. Yet, a number of species seem to partake naturally in "psychedelic" and "entheogen" drugs. Could they experience variations of what the mystic or shaman calls divine madness? ${ }^{6}$

"Verticality is the vector of mystery and reverence," Anthony Steinbock explains in his phenomenological study of religious epiphanies and mysticism (Steinbock 13). This vector of transport enables "in each of us...something like a conversion experience," writes novelist J.M. Coetzee, who firmly believes that conversion is the only likely path for human enlightenment regarding our treatment of other animals (Coetzee 89). Our question here is whether these mystical heights of moral and spiritual enlightenment could be attained not just by humans but also by some significant range of other species. 


\section{Mirror, Mirror on the Wall, who's the Fairest ... Toward an Interspecies Model of Enlightenment}

The central Darwinian insight that ethics evolves out of the needs, desires, and relationships among social animals is by now fairly well established. Frans de Waal foregrounds dimensions of primate social infrastructure such as forgiveness and reconciliation. Philosophers have ignored the larger implications of de Waal's research, and focused narrowly on his analysis of empathy for locating the social glue of societies. This analysis lays out various stages of empathy in terms of capacities that are theorized as produced by "mirror neurons" and measured through the "mirror recognition test." Mirror neurons are said to explain how mimicry of affect occurs at the cellular level, allowing the viewer to literally feel another's pain. Self-recognition as measured through the capacity of an animal to recognize itself in a mirror is said to underlie a self-other distinction required for the capacity to understand another creature's perspective. This capacity for understanding another is proposed to constitute possessing a "theory of mind," and interpreted as a cognitive skill. Yet this particular arsenal of building blocks-empathy, mirror neurons, the mirror recognition test and theory of mind - all reflect a distinctly modern human conception of the self.

The modern model of the self culminates in a bounded individual ontologically separate from others and ruled by reason. Mirroring empathy flattens the multiple dimensions of affect attunement that bind together animal societies. The modern model insists that the capacity for understanding the perspective of others hinges on a capacity for self-recognition. Yet selfawareness is measured too narrowly, I think, through the Mirror Recognition Test. Scientists observe whether animals with, say, an orange mark on their faces indicate awareness of this mark when peering into a mirror. Great apes, dolphins, and occasionally elephants (who lack 
good vision) do pass this mirror test. However, other species, including the dog, fail this particular test, despite significant ethical sensibilities and alternative modes of self-and-other awareness.

Marc Bekoff explains that dogs have a special ability to distinguish the unique qualities of their own individual urine from that of other dogs, suggesting that, at least for some species, encounters happen not necessarily face-to-face but snout-to-crotch (Bekoff 39). The fact that dogs are capable of using their signature product as a prop for self-awareness - much as humans delight in using a mirror for our self-image — challenges the relevance of this or any other human device for measuring self-identity. The canine capacity for self-reflection also gives new meaning to the old proverb that every dog smells its own self first. This uncanny means for canine self-recognition has some pungent implications for human theorizing on the intrinsically abject as a boundary for the self-dogs clearly don't think that their own urine stinks. They also express strong interest in that of others, apparently identifying others through their distinct waft. ${ }^{7}$ The fact that the abject or disgusting can vary across species, cultures, and individuals misleads us into thinking that others lack a sense for it at all. The same variation in recognition of selfand-other boundaries can also mislead us regarding tests for self-awareness. The dog's capacity for self-recognition through the smell test might strike some of us as disgusting but then the overemphasis on self-images gleaned from reflective surfaces can strike others as a bit narcissistic or Western. Malini Suchak remarks, "There are a lot of problems with this test including the fact that Kenyan children upwards of age 6 do not pass it. No one would suggest they do not have a sense of self" (e-mail communication, April 30, 2013). The mirror recognition test as a cultural gauge of selfhood may serve to reinforce, rather than question, modern 
metaphysical dogmas of the self as inherently bounded, atomistic, asocial, and split off from nature and others.

The variation in modes of self-awareness is important to catch because selfhood has long been thought to be crucial for any significant capacity to engage social norms that ground genuine ethical behavior. Any purported criterion would have to acknowledge divergences across species and cultures. By the canine standards of self-awareness, humans fail the test. Note though that a dog can be a human's best friend, indicating that social norms can be shared despite diverging modes of self-awareness and self-constitution.

Along with the mirror test for self-recognition I question the moral relevance of a cognitive theory of mind. Consider what it might mean if the other whom one understands via a theory of mind is (no insult intended) a veritable birdbrain. De Waal presents as a striking example of empathy a captive bonobo named Kuni in a British zoo who attempts to assist a fallen bird to freedom by spreading its wings and tossing it in the air for flight. ${ }^{8}$ We will return to this example in the next section. The question is whether the targeted help of strangersindeed, in this case, across species lines - might require an alternative model to one that culminates in the "high-stakes testing" of other animals, first for a sense of self through the mirror recognition test and, second, for any concept-based theory of mind. In assisting an unfamiliar starling - the proverbial bird of a different feather-Kuni indicates that she understands the bird's intentions and conscious emotions, and demonstrates a concern for a stranger without shared evolutionary ancestors. Again, dogs too are impressive creatures in this regard. They are known to rescue strangers and not just to bark at them. These and similar examples of a targeted helping suggest that, at least on occasion, something other than theoryand-concept-guided cognition or mirrored selves may explain an ethical concern for strangers. 
A highest stage of morality, if I understand de Waal correctly, is said to be evident only in humans. In this instance, de Waal argues that only humans demonstrate a capacity both to internalize the perspectives and needs of others or of their society, and to reflect rationally upon these internalized perspectives in determining their own goals:

We, humans, follow an internal compass, judging ourselves (and others) by evaluating the intentions and beliefs that underlie our own (and their) actions. We also look for logic.... The desire for an internally consistent moral framework is uniquely human.... I consider this level of morality, with its desire for consistency and 'distinterestedness,' and its careful weighing of what one did against what one could or should have done, uniquely human.... Our internal dialogue ... lifts moral behavior to a level of abstraction and self-reflection unheard of before our species entered the evolutionary scene. (de Waal et al. 174)

At this stage, moral judgment is self-reflective and often logically reasoned, presumably, from internalized principles or abstract ideals (de Waal et al. 168).

An important implication seems to be that other species could not experience the emotions of shame, guilt, or pride because these states internalize perspectives of the community. Only humans internalize social norms or expectations and justify rational rules based on them. However, consider the pride that the famous bonobo Kanzi displays when he refuses to apologize until months after an act of retribution against a perceived violation. Kanzi lives in the Great Apes Trust in Iowa with his human mother, Sue Savage-Rumbaugh, who taught him written (via a keyboard) and oral human language. ${ }^{9}$ This male bonobo once overheard a verbal attack on Sue by a visiting investigator, and commanded his human friend and researcher, William Fields, to punish the visitor. When the friend refused, he bit off part of his friend's finger, and did eventually apologize but only after months of attempting to renew the friendship. He signaled his shame by keeping his head and his gaze down, and even "elected to punish himself" by separating himself from the group (Savage-Rumbaugh 175). These examples suggest 
that the two capacities - one for internalization and the other for systematic, abstract reasoning (as displayed by Kant, Hegel, and Mill)—might be kept distinct.

While insisting that the science does not support a metaphysical break between humans and animals that would undermine the genuine ethical capacities of other species, de Waal yields to the claim of his Kantian and utilitarian critics that there may be "no parallels in animals for moral reasoning" (Savage-Rumbaugh 174) He observes that this moral reasoning includes a "desire for an internally coherent moral framework," and a concern for "why we think what we think." Yet social norms do not require an abstract statement, as expressed in the propositional form of the Golden Rule, and defended in systematic treatises of academic philosophy. Social carnivores enact the Golden Rule through styles of social cooperation and in playful interactions, sometimes across rank and species lines (Savage-Rumbaugh 174).

\section{Immanent Transcendence and Moral Symbol}

How does an enlightened attitude toward the stranger enter into our shared animal lives? No doubt some kind of ontological break is required from everyday pursuits of food, sex, and alliance; however, the meaning of this break is not at all clear. Recall that Coetzee believes that only through a conversion might we humans find compassion for the suffering of other species. Compassion, or agape, understood as an unbound and universal love, carries an element of transcendence missing from ordinary community-bound sentiments and rituals. Do other animals exhibit anything like agape in their approach to others?

With the completion of his magisterial Phenomenology of Spirit (1807), Hegel believed that he had culled from the tradition of Western philosophy the steps on the ladder for access to the real. Among the steps he included the development of self-consciousness as the acquisition 
of freedom through the transcendence of our animal nature. The fear of death was thought to be the ultimate marker of an animal nature, and by overcoming this fear humans display an ability to rise above all other animalistic desires as well. This presumed difference with regard to transcendence experiences between humans and animals recurs in Western philosophical traditions. Kant offers another version in an oft-quoted reflection from his Critique of Practical Reason (1788): "Two things fill the mind with ever new and increasing admiration and awe, the more often and steadily we reflect upon them: the starry heavens above me and the moral law within me" (133). Given the legacies of Kant and Hegel, we are not surprised to find the problematic metaphysics of a gap between the free and rational mind of men ("the world of reason") and deterministic animal life ("the sensuous realm") recur in twentieth-century philosophy.

What if we returned to the notion of transcendence without the anti-animal metaphysics, especially if any purported animal-human gap has less to do with unique human capacities than with the rise of urban centers and the loss of contact with other species and their habitats? Hunter-gatherer societies from the past lived amidst a variety of animal species, and most likely had skills of communion and communication with other species that have faded from modern cultures. The revolutionary thinker Marcuse, who artfully combines Hegelian dialectic and Kantian ethics, questions the anti-animal metaphysics. ${ }^{10}$ Like Kant and Hegel, he characterizes human history in terms of a growing estrangement of the spiritual from the sensuous realms of experience. But unlike most of the Western tradition, he finds redeeming value in an ancient spirituality experienced "erotically," and rooted in the sensuous passions: "The notion that Eros and Agape may after all be one and the same - not that Eros is Agape but that Agape is Eros- 
may sound strange after almost two thousand years of theology" (Marcuse 210). Liberated from metaphysical distortions, transcendence has profound implications for interspecies living.

Scientific studies provide some evidence for this non-metaphysical transcendence. Meditation or repetitive movement and chanting, especially when performed as part of a collective ritual, have been observed to deactivate certain "orientation association areas" in the brain's parietal lobes, resulting in the oceanic experience reported by shamans and mystics (Haidt 236; Newberg, D’Auili, and Rause). Moreover, the studies point out, these related states of unbound immersion (sometimes induced by naturally occurring "drugs") may be experienced by species with brain structures parallel to those of humans, and that seem to respond similarly to hypnotic rhythms.

If this brain science is right, the streams in the African forests may be among those sites that can conjure what we humans through our myths and romances portray romantically as the mystical repose and wild transformations of "green worlds beyond city walls" (remember Plato's erotic dialogues) - for us and for other species (Frye 183; Cavell). Jane Goodall suspects that the ecstatic dances of African chimpanzees occasioned by waterfalls and violent gusts of wind "may be stimulated by feelings akin to wonder and awe" (Goodall 1303-1306). ${ }^{11}$ Michael Tobias witnesses immanent spirituality swimming in the ocean among whale sharks: "These sharks exhibit bliss, the ultimate state of meditation and indwelling referred to by such diverse luminaries as Buddha and Thoreau" (Tobias 173). Katy Payne has discovered meditative moments among elephants. ${ }^{12}$ The baboons in Gombe National Park display signs of reverence and awe in their communion at the still pools along the path to the sleeping trees, as Smuts discovered. And, Smuts finds a spiritual connection similar to baboon sangha with her dog, Safi, in a respite from a game of fetch played, yes, by a stream, where Safi caught Smuts's gaze and 
elevated her melancholic mood: "She held her position and my gaze for about twenty minutes and then quietly approached and lay down next to me. My dark mood vanished. This was my first lesson in meditation" (Smuts 306). These spiritual experiences may partake not only of nature's beauty but also of the sublime mystery of its incomprehensible force. Whether an experience of the sublime or the beautiful can achieve an ethical character for these nonhuman species requires yet more speculation.

Yet, this speculation is also not without some basis. Consider the acts of compassion witnessed in other species. The alpha male chimpanzee named Freddy in Disneynature's 2012 documentary film Chimpanzee adopts a starving orphan named Oscar who has been rejected by the rest of the community - surely an act of moral beauty. Even more of a wonder is Kuni, the bonobo who assists the feathered stranger who lands in her cage, and whom she is destined to never see again, to a freedom that she will never know:

Kuni picked up the starling with one hand and climbed to the highest point of the highest tree where she wrapped her legs around the trunk so that she had both hands free to hold the bird. She then carefully unfolded its wings and spread them open, one wing in each hand, before throwing the bird as hard as she could. (de Waal et al. 31)

For de Waal, Kuni's act seems to display the highest type of empathy, indicating that she possesses a theory of mind. But, perhaps rather than an abstract concept of the bird's mental thoughts, the drive for freedom as expressed symbolically in the unfolded wings of the bird in flight spurs Kuni's compassion. ${ }^{13}$ More than an exercise of abstraction, or theory-and-conceptguided empathy, this compassion may be symbol-driven, and truly sublime. Recall that symbols operate between the sensory and conceptual realms, offering intelligible meaning that is not fixed by well-defined concepts. Here we have a symbol-guided compassion, and perhaps the basis for 
a highest stage of morality without need for determinate (concept- or law-based) judgments. Vivid symbol, not dry concept, may guide an unexpected and elevated response to the stranger.

Jonathan Haidt explains the psychological basis for moral beauty in terms of heightened sentiments experienced upon witnessing an act of kindness (Haidt 195-7). This experience of moral beauty results from an activated vagus nerve in the parasympathetic nervous system, which calms, and undoes the arousal activated by the sympathetic (fight-or-flight) system. The "vagus nerve works with the hormone oxytocin to create feelings of calmness, love, and desire for contact that encourage bonding and attachment," which is understood as significant for mothers and children (Haidt 197). Freddy's adoption of young Oscar seems to engage generous impulses that promote attachment.

The bonobo's concern for the bird, however, does not rest on any expectation for intimate attachment or friendship's eventual reciprocities. This act of compassion suggests a capacity for generosity that is unbound by any normal interest or attachment desire of any kind. It may overcome disgust of the repulsive or fear of the threatening through the sympathetic system. Modern moral theory treats this capacity as a pure form of altruism but more can be said. The self-sacrifice for a stranger bears the spiritual overtones of Christian agape or Buddhist Karuna. ${ }^{14}$ This sublimation of biosocial eros is sublime.

Moral disgust functions to establish firm commitments to personal and social boundaries; the moral sublime breaks these boundaries down. From the sublime's elevated stance, the self and its concerns appear small or insignificant (Kant). Spiritual rituals may attempt to develop this capacity, or "desubjectifying incapacity" (as theorized in alterity ethics), through cathartic practices that undo the ordinary boundaries of the self, allowing for participation in a reality beyond narrow needs and normal social desires. This experience 
diminishes the ego and yet it also channels agencies beyond individual powers that elude verbal expression or conceptual understanding (Haidt 201). Here is an unbound connectivity that is receptive and nonjudgmental. Ethical comportment no longer depends on membership in a particular community or society, and on expectations for social reciprocity. ${ }^{15}$ The alterity ethics prominent in continental ethics reappears, but not just in our human compassion toward animal others, but as a distinct possibility in those other animals as well. ${ }^{16}$ Is this what the baboons find reflected back to them from the still pool? For these baboons, chimpanzees, orcas, elephants, and dogs, is water a moral symbol?

Science resonates with reports from African societies on surviving practices of interspecies fellowship. In a comparative study of African and Western attitudes toward wild animals, Workineh Kelbessa explores Oromo attitudes through a rich anecdote:

Once upon a time, baboons had multiplied and disturbed the people in Yayo locality in Illuababorra zone. They destroyed crops and made life very difficult for the people. The people then decided to chase away the baboons from their locality. After a while the area was hit by serious famine for seven years. All crops were ruined. The people were wondering how to explain the cause of the present famine. After reading an animal's entrails, a prophet told the people how to solve this serious problem. He advised them to bring baboons back by performing a traditional reconciliation ceremony. The people were advised to ask the baboons for forgiveness by splashing maraacaa and asking them to eat their crops. He also advised them to sow crops on the border of their farmland specifically for baboons. The people then did what they were told to do. The baboons returned to Yayo after one year. Since then the Yayo people have never faced serious famine. (Kelbessa)

This wisdom tale relates how humans and nonhumans join together in peace-making reconciliation ceremonies. $^{17}$

Other Oromo stories relate the significance of sacred places where wild animals run to secure a refuge that is mutually recognized by them and their human hunters. At the end of his study, Kelbessa reaches the conclusion: 
What is distinctive to the Oromo tradition is that their beliefs and practices have contributed much more to the preservation of animal species than the Western beliefs and practices.... In Oromo society it is not only a group of individuals who have positive attitudes toward nonhuman species but also the society at large, because there have been laws that have been shared by all members of the society....But in the West, it was mostly only some individuals (for instance, writers and religious leaders) who have been concerned with the rights of animals rather than the government and all members of Western society. (Kelbessa)

Perhaps it is not realistic for modern bureaucratic societies disconnected from nature's "wild justice" to have any sense for the rituals that make for a peaceful coexistence with other animal species. ${ }^{18}$ Yet, ethics need not entail an anti-animal metaphysics. Visionaries in other cultures bridge the gaps between the sensuous and invisible worlds by tapping into transcendent powers and the agencies of animals (along with the wind, plants, and water) for their healing rites and meditative practices. Those who engage in the oldest known religious complex, shamanism, have long believed that other animals have their own shamans and magical transformations (Campos). ${ }^{19}$ Most sutras in Mahayana Buddhism teach that the seed of spiritual awakening is found in every sentient creature (Gethin). Couldn't we humans return from time to time to the revitalizing meaning of nonhuman agencies, and the aspirational purity of compassion, even while acknowledging that like any animal we are ever susceptible to bouts of indigestion?

\section{Baboons in a Green World}

Barbara Smuts writes:

I felt like I was turning into a baboon. ... I had gone from thinking about the world analytically to experiencing the world directly and intuitively. It was then that something long slumbering awoke inside me, a yearning to be in the world as my ancestors had done, as all creatures were designed to do by aeons of evolution. (Smuts 299). 
Wouldn't it be funny if the ability to immerse oneself in the flow of life, that is, to live for a moment fully in the waves of the present - a state thought to determine animal modes of awareness as inferior to human consciousness - is in fact not the lowest stage of consciousness but the highest? Narcissus looked into a pool and saw an image of the self. The baboon sitting along the stream in sangha may for a moment lose the self rather than find it. In the stillness of that moment may be found - not nothing — but wonders untold. "All things are full of gods," Thales is reported to have taught (Aristotle 405a 19). Perhaps the fount of time that adventurers cross open waters in search of - the source for the reenchantment of our ordinary lives - is not lost in some far distant past or impossible future, but ever recurring in the depths of the moment—not above our human animality but running through it. Like water.

\section{Notes}

${ }^{1}$ JeeLoo Liu cautions that the use of this Buddhist term in this context may be experienced as insulting or wrong to those who cultivate meditative communities and practices after years of effort. I risk leaving Smuts's language with the hope that it will open up spiritual practices to a larger world rather than harming these practices or their reputation.

2 The approach here does not focus on renaturalizing the human so much as demonstrating the capacities for technology, knowledge, and ethics in other species, although I do not aim to exclude the former. On renaturalization, see Sharp; Grosz.

3 Buddhist scholar and director of Emory University's Tibetan Studies Program, Tara Doyle clarifies (in e-mail communication, April 22, 2013) that in Buddhism, enlightenment is the ultimate spiritual attainment, not a precursor to that attainment, and the term is typically used only when discussing that highest state, where no more suffering or negative emotions exist. Words such as states, realizations, attainments, perfections, etc. would feel more accurate, in a Buddhist sense, for the ethical and spiritual phenomenon that this essay describes. Many Buddhists would also be uncomfortable with assertions that nonhuman animals can be fully enlightened (although they agree that some might and do demonstrate what are typically considered advanced, wholesome mental states). When the Buddha was, in a past life, a rabbit or elephant he still wasn't seen as fully “enlightened," more like highly realized. This essay's 
challenge to the human exceptionalism that lingers in this tradition as well as in modern Western enlightenment traditions aims to open up the term to new meanings, while retaining from the term the verticality of an expansive awareness of self-and-world.

${ }^{4}$ On implicit bias, see "Implicit Bias and Philosophy," http://www.biasproject.org/.

5 I owe the suggestion to name a Narcissus gene to David Pena-Guzman. The Faustian and monkey narcissus genes in effect serve to reinterpret Marcuse's sharp contrast between the Prometheian myth and Narcissistic eros, which we return to later in the essay.

${ }^{6}$ David Linden says: "But do we really know whether these animals like the psychoactive effects of the drug, or are they just willing to put up with them as a side effect of consuming a valuable food source? After all, fermented fruit is a tasty and nutritious meal. While it's hard to dissociate these motivations in animals, many cases suggest that the psychoactive effect is the primary motivator for consumption. Often, only a tiny amount of plant or fungus is consumed, so while its nutritional effect is minuscule its psychoactive effect is large" (38).

7 Malini Suchak explains that "dogs have a capability we don't have-we can't distinguish individuals by their urine. It's the same reason why they stick their nose in human's crotches when they greet them, it's a way of identifying an individual. It serves a very real function. We just have different, more visually-oriented mechanisms for doing this" (email communication, April 30, 2013).

${ }^{8}$ On the baboon, see de Waal, Primates and Philosophers, 30.

${ }^{9}$ http://www.radiolab.org/2010/feb/19/ Much thanks to Swasti Bhattacharyya for this source. The story is from the Great Ape Trust in Iowa; see http://www.iowaprimatelearning.org/.

10 John Sanbonmatsu develops Marcuse and other Frankfurt theorists' critique of Western exploitation of animals, and alienation of human's from their own animal natures in the Introduction to his edited collection, Critical Theory and Animal Liberation.

${ }^{11}$ See also Goodall, "In the Shadow of Man."

${ }^{12}$ Katy Payne, http://www.onbeing.org/ aired originally on March 21, 2013.

${ }^{13}$ Compare the prophetic thoughts of Frederick Douglass on freedom: see Narrative of the Life of Frederick Douglass and "The Heroic Slave."

14 On differences between xenophobic chimpanzees and bonobos, who demonstrate altruism toward strangers, see Bhanoo. On Dame Daphe Sheldrick's observations on compassion in elephants, see Bradshaw 24. 
${ }^{15}$ Here's a significant point where I would aim to allow for a step further for the relational ethics approach that I share with Elizabeth Anderson (see Anderson 284); and with Donaldson and Kymlicka, among many others. Anderson bases social membership on discipline enforced by commands (authoritarian models of dog and horse training via Vicki Hearne in this case) rather than egalitarian play (see Smuts, "Encounters," 303). Cosmopolitical compassion brings back in aspects of Nussbaum's aim to generate the ethical wonder that secures the capacities of other animal species; see her "Beyond 'Compassion and Humanity" 306.

${ }^{16}$ See discussion of Levinas in Calarco (55-77), where Calarco aims to reinterpret what is at stake in Levinas in order to allow for compassion or other forms of ethical encounter across species barriers.

17 Sophisticated ceremonies such as these, as well as reconciliation and consolation within species, suggest that these animals do understand beliefs of others within and across species; this may involve holistic reading of others as persons in social roles as suggested in Andrews 231248.

${ }^{18}$ Term borrowed from Bekoff and Pierce.

19 Thanks to Anthony Bisignano for this reference. Shamanism is the oldest religious complex, and involves a visionary transformation that conflates human and animal selves, and a trance, or dual consciousness of spiritual and terrestrial worlds; animals also were thought to experience these transformations: see Stone; see also Lingis, where trance experiences, as "compassionate no-self, eyes open upon the universal impermanence," are explored in Sri Lanka (xi).

\section{Works Cited}

Anderson, Elizabeth. "Animal Rights and the Values of a Nonhuman Life." Animal Rights: Current Debates and New Directions. Eds. Cass R. Sunstein and Martha C. Nussbaum. Oxford: Oxford University Press, 2004.

Andrews, Kristin. Do Apes Read Minds? Cambridge, MA: MIT Press, 2012

Aristotle. Metaphysics. Trans. W.D. Ross. Oxford: Clarendon Press, 1958.

Bekoff, Marc. The Emotional Lives of Animals: A Leading Scientist Explores Animal Joy, Sorrow, and Empathy-And Why They Matter. New World Library, 2007.

Bekoff, Marc and Jessica Pierce. Wild Justice: The Moral Lives of Animals. Chicago: University of Chicago, 2010. 
Sindya Bhanoo, Sindya. "Milk of Human Kindness Also Found in Bonobos," New York Times: http://www.nytimes.com/2013/01/08/science/the-unexpected-altruism-of bonobos.html?_r=0.

Bradshaw, G.A. Elephants on the Edge: What Animals Teach Us About Humanity. New Haven: Yale University Press, 2009.

Calarco, Matthew. Zoographies: The Question of the Animal from Heidegger to Derrida. New York: Columbia University Press, 2008.

Campos, Don José. The Shaman and Ayahuasca. Trans. Alberto Roman. Studio City, California: Divine Arts, 2011.

Cavell, Stanley. Pursuits of Happiness. Cambridge, MA.: Harvard University Press, 1981.

Coetzee, John M. "Notes on Issues Raised by Matthew Calarco." The Death of the Animal. Ed. Paolo Cavalieri. New York: Columbia, 2009.

Damasio, Antonio R. Descartes' Error: Emotion, Reason, and the Human Brain. New York: Putnam, 1994.

De Waal, Frans. "The Cosmopolitan Ape Primatology: Empathy, morality, community, culture - apes can have it all!" (interview). Nautilus 1, http://nautil.us/issue/1/what-makes-youso-special/the-cosmopolitan-ape

De Waal, Frans, et al. Primates and Philosophers: How Morality Evolved. Eds. Stephen Macedo and Josiah Ober. Princeton and Oxford: Princeton University Press, 2006.

Diamond, Jared. The World Until Yesterday. New York: Penguin, 2012.

Donaldson, Sue and Will Kymlicka. Zoopolis: A Political Theory of Rights. Oxford: Oxford University Press, 2011.

Douglass, Frederick. Narrative of the Life of Frederick Douglass, An American Slave. Ed. Houston A. Baker, Jr. New York: Viking Penguin, 1982

— "The Heroic Slave," in Three Classic African-American Novels. Ed. William L. Andrews. New York: Mentor, 1990. 27-28.

Dubner, Stephen. "The Monkey Economy: Freakonomics Radio Live in St. Paul." accessed March 23, 2013, http://www.youtube.com/watch?feature=player_embedded\&v=J8449HgS3FM

Frye, Northrop. Anatomy of Criticism. Princeton, New Jersey: Princeton University Press, 1957.

Gethin, Rupert. Foundations of Buddhism. London: Oxford University Press, 1998. 
Goodall, Jane. In the Shadow of Man. Boston: Houghton Mifflin, 1971.

—. "Primate Spirituality." The Encyclopedia of Religion and Nature. Ed. B. Taylor. New York: Thoemmes Continuum, 2005.

Grosz, Elizabeth. Time Travels: Feminism, Nature, Power. Durham: Duke University Press, 2005.

Haidt, Jonathan. The Happiness Hypothesis. New York: Basic Books, 2006.

James, William. Varieties of Religious Experience. New York: Macmillan, 1961.

Kant, Immanuel. Critique of Judgement. Trans. James Creed Meredith. Oxford: Oxford University Press, 1973.

Kant, Immanuel. Critique of Practical Reason. Trans. Mary Gregor. Cambridge: Cambridge University Press, 1997.

Kelbessa, Workineh. "Indigenous and Modern Environmental Ethics: A Study of the Indigenous Oromo Environmental Ethic And Modern Issues of Environment and Development." Cultural Heritage And Contemporary Lifeseries I, Culture And Values, Volume 1. Accessed January 13, 2013, http://www.crvp.org/book/Series02/II-13//front.htm.

Kolbert, Elizabeth. "Annals of Evolution: Sleeping with the Enemy-What Happened Between the Neanderthals and Us?" New Yorker, August 15, 2011.

Linden, David. The Compass of Pleasure. New York: Viking Penguin, 2011.

Lingis, Alphonso. Excesses: Eros and Culture. Albany, New York: SUNY, 1983

Marcuse, Herbert. Eros and Civilization: A Philosophical Inquiry into Freud. Boston: Beacon Press, 1974.

Newberg, Andrew, D'Auili, E. and Rause, R. Why God Won't Go Away: Brain Science and the Biology of Belief. New York: McGraw-Hill, 2001.

Nussbaum, Martha. "Beyond "Compassion and Humanity". Animal Rights. Eds. Cass R. Sunstein and Martha Nussbaum. Oxford: Oxford University Press, 2004.

Plato. Symposium. Trans. Robin Waterfield. Oxford: Oxford University Press, 1994.

Steinbock, Anthony J. Phenomenology and Mysticism: The Verticality of Religious Experience. Bloomington, Indiana: University of Indiana Press, 2009. 
Sanbonmatsu, John. "Introduction". Critical Theory and Animal Liberation. Ed. John Sanbonmatsu. Lanham: Rowman and Littlefield, 2011.

Savage-Rumbaugh, Sue. "Sibling Rivalry." The Smile of a Dolphin. Ed. Marc Bekoff New York: Discovery Books, 2000.

Sharp, Hasanna. Spinoza and the Politics of Renaturalization. Chicago: Chicago University Press, 2011.

Smuts, Barbara. "Encounters With Animal Minds." Journal of Consciousness Studies, 8 (2001): 293-309.

Stone, Rebecca. The Jaguar Within. Austin, Texas: University of Texas, 2011.

Tobias, Michael. "A Gentle Heart." The Smile of a Dolphin. Ed. Marc Bekoff. Discovery Books, 2000. 